\title{
PLEA BARGAINING - A NEW CRIMINAL PROCEDURE INSTITUTION
}

\author{
A. Uzlău

\section{Andreea Uzlău} \\ Faculty of law and administrative sciences \\ Christian University Dimitrie Cantemir, Bucharest, \\ *Correspondence: Christian University Dimitrie Cantemir, 146 Splaiul Unirii, sector 4, \\ Bucharest, Romania \\ E-mail: stoicaandreea76@yahoo.com
}

\begin{abstract}
This work deals with the plea bargaining (plea agreement) as an institution which is intended to be entered by means of the new Romanian Code of Criminal Procedure, adopted by Law no. 135/2010, in the light of the conditions, of the conclusion procedure, of its contents and consequences. Similar negotiated justice proceedings are found both in the adversarial and in the inquisitive systems (USA, England, as well as in Germany, France, Belgium, Greece, Republic of Moldova, Czech Republic, Croatia.
\end{abstract}

Keywords: plea bargaining, simplified judgement proceedings, the new Code of Criminal Procedure

\section{Introduction}

The present study aims to spotlight a new criminal procedure law institution, the plea bargaining agreement, governed by the provisions of the new Romanian Code of criminal procedure, adopted by Law no. 135/2010 and which will enter into force on the date fixed by the implementing Law.

The work is structured around the main themes stemming from this topic, such as the notion and the reasons of the new simplified procedure, the conditions for application, the holders, the form and content of the agreement, the consequences of the agreement, the referral to the Court with the plea bargain agreement, the procedure before the Court, the solutions it can pronounce and the remedies.

Last but not least, it is analysed the compatibility of the regulation with the provisions of the European Convention on human rights, from the perspective of the right to a fair trial and the reasonable time.

The study aims to analyze the institution, in order to facilitate understanding and deepening the legal provisions of the new Code of criminal procedure.

The subject is of current interest both for theorists, most notably for practitioners of law, given the multitude of problems that will arise in this respect, in the jurisprudence of the Courts.

\section{The notion and the reason of the new simplified procedure}

The plea bargaining agreement is one of the main novelties introduced by the new Romanian Code of criminal procedure, the provisions being contained in Chapter I of title III, entitled "Special procedures", respectively, art. 478-488.

This analysis will take into account the provisions contained in the Law no. 255/2013 for the implementation of the Law no. 135/2010 - the Code of criminal procedure and on modification and completion of some legal acts containing criminal procedure provisions (hereinafter referred to as the implementation Law). 
The new Romanian Code of criminal procedure was adopted by Law no. 135/2010. The Preliminary Conclusions of the project were prior approved by the Government Decision no. 829/2007. The new Code of penal procedure will enter into force 1 February 2014.

According to the Explanatory Memorandum of the Code, the new regulation aims to respond to the requirements of predictability of criminal proceedings arising from the European Convention for the protection of human rights and fundamental freedoms and, implicitly, in the caselaw of the European Court of human rights.

As shown in the Explanatory Memorandum, it was not intended bz the new Code of criminal procedure to necessarily contain original solutions in comparison with the existing solutions that have been proven to be viable in practice, but to change the corresponding solutions that generated all those difficulties and to introduce new solutions based on comparative positive experiences or geared towards favourable effects expected, all as a result of the study of the relevant doctrine, the internal system and the European systems.

Therefore, the new Romanian Code of criminal procedure has kept its predominantly continental european character, but as a novelty, introduces many elements corresponding to the adversial trial, adapted to our own legal system.

As it has been noted in the doctrine, the procedure of plea bargaining agreement brings classic elements of negotiated justice, in which an accused who pleads guilty, agrees to be sentenced without a trial and to waive any right that may be granted.

The regulation complete thus the reform of the romanian criminal procedure, started by Law nr. 202/2010, that also introduced a new simplified procedure - judgment in the case of admission of guilt (art. $320^{1}$ of the actual Romanian Code of criminal procedure) a procedure that can also be found in the new Criminal procedura cod, art. 374. As the judgment in the case of admission of guilt, plea bargaining agreement is an abbreviated form of judgment for certain crimes, which aims to empower the parties to the proceedings and and at the same time to relieve the courts.

Inspired by the Anglo-Saxon law, the institution of plea bargaining agreement was taken gradually into the legislation and practice of States with continental legal system, so that, today, it is applied in one form or another in countries such as Germany, France, Italy, Hungary, the Czech Republic, the Republic of Moldova.

In adversial systems, the plea bargaining agreement is a traditional institution and aims to avoid the expensive and traumatic procedure with uncertain results; in fact, it is a negotiating positions of equality between prosecution and defence, and the result is a compromise whereby the Prosecutor accepts the defence plea in favour of guilt offering instead an accusation gentler (and hence a reduced sentence).

In these systems, the judge can only check the existence of consent of the accuser, not the facts.

In the continental law countries, the plea bargaining agreement differ considerably, especially in terms of the validation of the agreement by an independent judge, within certain limits, includindg the analysis of the facts.

In respect of the premises of the introduction of this procedure under national law, in the Explanatory Memorandum of the new Romanian Code of criminal procedure reads that, ,the plea bargaining agreement is an innovative legislative solution that would ensure the resolution of cases in a time-optimal and predictable, but it is also a remedy for eliminating the deficiencies of the judicial system, such as the excessive length of court proceedings, but also a means of empowering the parties to the proceedings and at the same time to relieve the courts."

In the regulation of the new Romanian Code of criminal procedure, subject to the plea bargaining agreement is the recognition of the crime committing and the acceptance of the legal classification on which the prosecution has been made. The negotiation involves the kind and amount of punishment, as well as the form of its execution. 


\section{The compatibility of the regulation with the provisions of the European Convention on human rights}

The plea bargaining agreement does not violate the provisions of article 6 parag. $3 \mathrm{~d}$ ) of the European Convention on human rights (hereinafter referred to as the Convention), which guarantees a defendant the right to inquire or seek prosecution witness hearing and to obtain the attendance and hearing of the defence witnesses under the same conditions as prosecution witnesses.

This right is relative, the accused may waive its exercise before an independent and impartial court, and choose to be judged on the basis of evidence collected in the criminal investigation phase.

In this sense, the Court in Strasbourg (judgment of 28 august 1991, Brandstetter v. Austria case) has shown that the defendant has the possibility to opt out of the right guaranteed by article 6 parag. $3 \mathrm{~d}$ ) of the Convention and, therefore, cannot claim that this right has been violated, if the national Court bases the convinction on the statement given during the criminal investigation phase by aprosecution witness (including witnesses with protected identity), whose hearing the accused has waived.

Art. 6 parag. 1 of the Convention provides for the right of all persons to a fair hearing, publicly and in a reasonable period of his cause. The European Court of human rights has shown that the examination in a reasonable period of each case is a procedural guarantee. its purpose is to protect all the litigants against the excessive length of the proceedings.

Such a provision emphasizes that the judiciary should not be performed with a delay that could compromise its efficiency and credibility.

The reasonableness of the procedure shall be assessed according to several criteria: the complexity of the case, the conduct of the parties, the conduct of the authorities, and the importance for the parties to the proceedings. Only delays due to the behaviour of the authorities are likely to give rise to violations of the European Convention.

The European Court of human rights has held that States must respect an obligation of result: trial within a reasonable period of time. The means chosen to achieve this result are left to the discretion of States. As a result, our internal system will include the plea bargaining agreement.

\section{Conditions of application}

a. The agreement may be concluded in the course of criminal proceedings, but after setting in motion the criminal action under art. 309 of the new Romanian Code of criminal procedure, i.e. as soon as it becomes apparent that there is evidence which shows reasonable grounds for believing that a person has committed a crime and there is any of the foreclosure cases (art. 16 of the code).

This is logical, given the fact that the criminal responsibility of the perpetrator involves the existence of sufficient evidence of guilt and that only from this moment the suspect is indicted and has unlimited procedural rights and the possibility of an active contribution to the establishment of criminal liability.

Moreover, as stated in the doctrine, whereas with regard to suspect there is only a reasonable suspicion that he committed a criminal offence prescribed by the law, to recognize the possibility of concluding the agreement would mean a damage of the right against self incrimination.

b. The agreement is accomplished on the initiative of the Prosecutor or the accused.

The agreement is preceeded by the opinion of the Prosecutor upwards, which establishes the effects and limits of this initiative. This provision is similar to that concerning the verification of the legality and solidity of indictment by the Prosecutor upwards.

We appreciate that the opinion of the Prosecutor upwards is obligatory for the Prosecutor of the case. The least will conclude the said agreement with the defendant without creating an easier situation than that envisaged by the Prosecutor upwards. 
For example, in its opinion, the Prosecutor upwards may establish the minimum and maximum limit of punishment that can be negotiated, or may set a maximum threshold below which it cannot pass, may require a certain type of the execution of the punishment, etc. If the defendant would agree, for example, with a different way of enforcing the penalty, which is not among the ones set by the Prosecutor upwards, the agreement cannot be completed.

We believe that the Prosecutor of the case could get a situation more difficult for the accused, and this circumstance wolud not constitute a violation of the opinion of the Prosecutor upwards. in reality, such a situation could only reach as far as the defendant would not have knowledge of the contents of the opinion. However, from the analysis of the law and of the reasons for the institution's existence, it follows that the defendant will know the bounds between which the Prosecutor of the case can "negotiate".

It should be noted in this context that the right of the accused to enter into an agreement is not an absolute right, the Prosecutor is not obliged to enter into such an agreement even if the legal conditions, as provided by law, are met.

The Prosecutor, with the consent in writing of the hierarchically superior prosecutor, is the sole power to decide the topic concerning the conclusion of an agreement in the State. In making this decision, can be considered as elements of the defendant's will to cooperate with prosecution or prosecution of other persons; attitudes towards criminal activity and criminal antecedents; the nature and severity of the indictment; probability to obtain the condemnation in the case in question; public interest to achieve a more efficient trial with lower expenses.

If the agreement is initiated by the Prosecutor, the defendant has the possibility to request the Prosecutor to grant a term, in which he can reflect on his proposals, in order to satisfy the rights of the defence. With regard to the form that the initiative for its conclusion has to take, we appreciate that, although the law does not provide, in principle it should be a registered document, in which the defendant or the Prosecutor to understand under what conditions projected should be that agreement concluded.

c. Effects of plea bargaining agreement are subject to the opinion of the hierarchically superior prosecutor.

The scope of the concept of effects of plea bargaining agreement being given, we appreciate that you have to assume the existence of an agreement already concluded validly, which is only likely to have an effect. In this situation, the role of the hierarchically superior Prosecutor's opinion is to make bringing the agreement of the Prosecutor in court. Thus, it can be inferred that the notice is placed in time subsequent to agreement and prior to referral to the Court with it.

This provision leads to the existence of two consecutive opinions, one targeting boundary agreement, and second, to acceptance of the hierarchically superior Prosecutor as the Court is seised with the agreement already concluded. We consider that de lege ferenda it is necessary to clarify the text.

d. The agreement is an optional procedure that can end only with respect to offences for which the law provides the penalty of fine or imprisonment not exceeding 7 years. Art. 480. (1) is limiting, therefore, the scope of application of the agreement to the crimes of a small or medium gravity, this limitation being, of course, justified by the degree of danger of the acts committed.

e. Agreement procedure shall apply only when, from the evidences taken, it appears that there are sufficient data on the existence of the offence for which the criminal proceedings started and with respect to the guilt of the accused.

In this respect, of the evidence necessary for the validity of the agreement, without any doubt, this institution that is expected to appear in the Romanian legal landscape has an important consequence. Negotiated waiver involves, from the start, a waiver of one of the main effects of the presumption of innocence, namely the right of the accused not to be convicted only on the basis of legally administered and evidence strong enough to remove any 
reasonable doubt in the mind of decisional party-the Court. Although a level of probation still remains necessary for the validation of the agreement by the Court, the standard of proof beyond any reasonable doubt, that is, by default, stipulated in our criminal law, suffers an important collapse, even by the consent to the agreement of the accused.

f. Unlike the procedure judgment based on guilt, the law prohibits juvenile defendants access to this procedure (art. 478 para. 6 of the new Romanian Code of Criminal Procedure), as an additional protection for them, in respect to the vulnerability of the age. In the absence of other rules, we have to conclude that such agreements cannot be concluded either personally, with the consent of the legal representative, in the case of minors with limited exercise capacity, or, even less, by legal representative, in the case of those deprived of exercise capacity. However, de lege ferenda,if provisions relating to persons summoned to attend any hearing or confrontation of the minor and for minors who have reached 16 years of age were extended, we appreciate that an agreement would be appropriate also if the defendants are minors. Of course, in this hypothesis, provisions regarding the limits of punishment applied to juvenile offenders should be related.

g. As a guarantee of procedural rights, art. 480 (2)of the new Romanian Code of Criminal Procedure provides that at the conclusion of the plea bargain, legal assistance is mandatory. Therefore, the legislation assigns a particular importance to the defendant in the context of this procedure, his activity aiming the assessment of suitability for conclusioning the agreement and assistance in the negotiation of the penalty and the way of its execution.

In the original form of the draft of the new Romanian Code of Criminal Procedure there was not provided the mandatory judicial assistance during the procedure for negotiating plea bargain agreement, gap that was likely to leave without adequate legal protection a large category of persons. Through Law No. 135/2010 on the Romanian Code of Criminal Procedure, the mandatory legal assistance only for the time the agreement is plea bargaining had been expressly provided.

We appreciate this modification useful, given the fact that, by the conclusion of a plea bargaining agreement initiated by the Prosecutor, the defendant waives the right to be judged within a full trial and so, a number of procedural rights and guarantees are not granted. Therefore, the defendant must understand fully and clearly the circumstances surrounding that decision. In this regard, a major role is confered to the Defender.

\section{The holders of the agreement}

The agreement has a consensual and personal nature, being discharged, in the case of participation, with each participant individually, separate and distinct, without the need, however, to conclude an agreement with all participants in the crime.

According to art. 478 (2)of the new Romanian Code of Criminal Procedure, if the criminal proceedings has been set in motion against several defendants, a separate plea bargaining can be won with each of them, without any harm being brought to presumption of innocence of the defendants for whom no agreement has been concluded.

More favourable conditions which would benefit to one or some of the participants in the case of concluding a plea bargain agreement might not affect the presumption of innocence of the defendants for whom no agreement has been concluded. On the same line, the right of the Court to admit the plea bargaining agreement only in respect of one or some of the defendants is recognized [art. 485 (2) of the new Romanian Code of Criminal Procedure.

Separation of court procedures is carried out in practice, by disjunction of the case, fact which might be imposed, since the law does not distinguish, also in case of indivisibility.

Some criminal procedural legislation prohibit the conclusion of an agreement if at least one of the participants will choose the ordinary procedure.

Equally, it must be established which is the purpose of the wording "without any harm being brought to presumption of innocence of the defendants for whom no agreement 
has been concluded". In this respect, there is a point of view of doctrine, which we definitly agree. ${ }^{1}$

The mentioned author materializes this provision in the obligativity of the Attorney not to mention in the declaration of plea bargain of the defendants who have reached the agreement, data concerning the defendants which have not concluded such an agreement.

In the reasoning behind this interpretation is relevant also the circumstance that, in the event that the agreement ends only in respect of some of the facts or only in respect of some of the defendants, and the rest of the acts or defendants are sent to Court, the Prosecutor submittes to the Court only prosecution documents that relate to facts and persons who have been subject to plea bargaining agreement.

In this context it is born a practical problem, namely what happens when legal classification is determined by the number of participants, and only one of them picks the special procedure. In this case, the legal classification of the offence cannot be established, without the reference to the participation of other persons from committing the offence. For these reasons, we appreciate that, at least for cases of indivisibility situation, it is necessary to stipulate that the agreement cannot be concluded if at least one of the participants choose the ordinary procedure.

As shown, the agreement shall be concluded between the Prosecutor and the defendant, without the participation of the injured person. De lege ferenda it should be regulated the right to be informed about the agreement to be concluded, such a regulation being in line with the European Community which provide for the right of persons injured by committing crimes to be informed and to be heard in criminal proceedings.

\section{The form and content of the agreement}

Plea bargaining agreement ends in written form and shall contain the particulars referred to in article 482 of the new Romanian Code of Criminal Procedure.

As published in the code, these provisions provide that the plea bargaining agreement shall contain particulars concerning: the date and place of conclusion; name, surname and the quality of those who end the conclusion; data concerning the defendant, prescribed in art. 107 (1); the description of the offence forming the subject of the agreement; the legal classification of the offence and the penalty prescribed by law; evidence and probation; the express statement of the defendant whereby acknowledges committing the offence and the legal framework through which the criminal proceeding was put in motion; Prosecutor demands; the signatures of the defendant, the Prosecutor and of the lawyer.

In the form modified by Law enforcement, the Prosecutor's claims were detailed, specifying that the agreement will have to include information about the type and amount of punishment and the enforcement's shape. We also appreciate that justifiably was made so that the agreement can lead to a waiver of punishment or deferment of the application of the penalty, so that negotiation between Prosecutor and defendant is no longer limited to the conviction. We note, thus, a set up of a role at all neglected of the Prosecutor and the accused, including the process of determining the amount of the penalty.

\section{The consequences of the agreement}

According to the article 481 (2) of the new Romanian Code of Criminal Procedure, in the event that agreement is concluded by the plea bargain, the Prosecutor may not draw up the indictment with defendants which he has concluded the agreement.

As published, under art. 480. (3) of the new Romanian Code of Criminal Procedure: "the defendant has reduced by one-third of the limits of the punishment prescribed by law if the prison sentence, and one-fourth reduction of the limits of the punishment prescribed by law, in the case of the fine". The law for implementation repealed art. 480 (3). We appreciate that such a solution is liable to criticism, as it is likely to deter the defendants to conclude the

S. Siserman, Consideraţii privind acordul de recunoaştere a vinovăţiei, available online at http://www.juridice.ro/163263/consideratii-privind-acordul-de-recunoastere-a-vinovatiei.html. 
agreement at the stage of prosecution, which could benefit from a similar reduction of the limits of punishment, by applying the plea bargaining during the trial.

\section{Referral to the Court with plea bargaining agreement}

Plea bargaining agreement is subject to the supervision of the Court with respect to its subject matter and the conclusion. The role of the judge is to ascertain whether the agreement has been concluded in accordance with the law and whether there are sufficient evidences confirming the conviction. Reporting to this, the Court may, whether or not to accept the agreement.

Thus, according to art. 483. (1) of the new Romanian Code of Criminal Procedure, after the conclusion of the plea bargain, the Prosecutor shall refer the Court to which it would return power to judge the case and sends its plea bargaining agreement with the prosecution atcs, the only criminal acts that relate to facts and persons who have been subject to agreement of plea bargaining.

According to paragraph (2) of the same legislative text, in the event that the agreement ends only in respect of some of the facts or only in respect of some of the defendants, and other acts or defendants are sent to Court, the referral to the Court is made separately. Also, if prior the agreement there has been a settlement or an agreement to mediate between the accused, the civil party and the one responsible according to the civil law, as reffered in article. 23. (1) of the new Romanian Code of Criminal Procedure, the Prosecutor submittes to the Court such acts, also.

\section{The procedure in Court}

Upon receiving the request, the Court shall verify the formal conditions of plea bargaining agreement, and if it finds any lack of mandatory metters or if those were not complied with the conditions laid down in article 482 and 483 of the new Romanian Code of Criminal Procedure, it provides coverage of omissions in not more than 5 days and notifies accordingly the Prosecutor who issued the consent.

According to the article. 484. (2) of the new Romanian Code of Criminal Procedure, if formal requirements are fulfilled, the Court shall pronounce upon the plea bargain by sentence, by an noncontradictory procedure, in open court, after hearing the accused and lawyer as well as a civil party, if present.

According to the article. 487 in the new Romanian Code of Criminal Procedure, the sentence shall compulsory provide:

a) the particulars which it must contain and the decisions of the meeting, and the exposure of a sentence which is pronounced at first instance;

b) the deed for which ended in a plea bargain agreement and its legal classification.

\section{The solutions the Court could sentence}

With regard to the solutions the Courtcould sentence, those are referred to in art. 485 . (1) of the new Romanian Code of Criminal Procedure.

Thus, if the conditions are met as in art. 480-482 of the new Romanian Code of Criminal Procedure with regard to all the facts the defendant was retained to and which were the subject of the agreement, the Court recognizes the plea bargaining agreement with one of the solutions provided for in art. 396. (2) to (4) of the Code, namely the condemnation, giving up at sentencing or defering application of punishment, solution that cannot create a culprit heavier than that on which they arrived at an agreement.

Please note, however, that punishment and its execution procedure laid down in the agreement does not bind the Court, which may proceed to a reindividualization of the penalty or the manner of its execution, without creating to the defendant a heavier situation.

We appreciate that this regulatory option is liable to criticism, as it is likely to create a reserve on the part of the Prosecutor to enter into plea bargaining agreement, given that he cannot quantify exactly what benefits will be from the negotiation with the defendant. A more suitable solution would be to regulate the obligation of the Court to sentence the conviction within the limits laid down in the agreement, in terms of the amount of the penalty and the 
shape of its execution, of course provided that they are legally established, otherwise rejecting the agreement.

At the same time, according to art. 485. (2) of the new Romanian Code of Criminal Procedure, the Court may admit the plea bargaining agreement only for some of the defendants.

If the conditions are not met as in art. 480-482, the Court rejects the plea bargaining agreement and sends the dossier to the Prosecutor for further prosecution, pronouncing at the same time ex oficio about the custody state of the defendants. Through implementation law it is introduced a new case for the rejection of the agreement, namely the situation where the Court considers that the solution that was reached an agreement between Prosecutor and defendant is unreasonably mild in relation to the seriousness of the offence or the offender dangerousness. This provision softens the conventional character of the agreement, by setting up a greater role of judges in the process of individualization of punishment, as an important part of the Court's function that he meets. In this way, the regulation departs from the adversial form and is coming to the specific features of criminal process of continental style, in which the judge does not have just a referee role, but active role in finding out the truth in all aspects.

It is noted that the new Romanian Code of Criminal Procedure does not provide guarantees for the preservation of the presumption of innocence where plea bargaining agreement is rejected by the Court. Versus the need to protect the defendant's rights, in particular of the silence and self disincrimination, we appreciate that it is necessary to clarify that the recognition of facts by the defendant cannot be used against him.

With regard to the settlement of civil action, in the case of acceptance of the agreement, art. 486 of the new Romanian Code of Criminal Procedure, as published, provided that if between the parties ended in a settlement or mediation agreement with regard to the civil action, the Court takes note about that by sentence. In other cases, the Court may decide disjoining the civil action and send it at the competent Court according to the civil law, when settling the civil side would delay the settlement of the criminal process. In the form modified by implementation law, this text provides that where the parties have not concluded the transaction or agreement to mediate, the Court leaves unresolved civil action, in this case the decision was upheld by the plea bargain agreement having become final in the civil Court.

The solution is natural, since the civil settlement is no longer subject to the judgment in the form of special procedure of plea bargaining, civil action could have been resolved either through a separate application addressed to civil Court, or through an alternative means of dispute resolution.

\section{Legal remedies}

Against the sentence handed down under art. 485 of the new Romanian Code of Criminal Procedure, the Prosecutor and the defendant may declare the appeal within 10 days of receipt.

Through draft of implementing law, article 488 of the Romanian Code of Criminal Procedure is modified, providing expressly that against the decision by which the recognition was admitted, it may be declared appeal solely on the kinds and amount of punishment or execution form, other reasons being excluded.

We appreciate this provision justified, provision which is intended to contribute to achieving the main aim of this simplified procedure, by relieving Courts and ensuring as much as possible a short lasting Court proceedings, while constituting a mean of empowering parties in the process.

It is objectionable, however, the fact that it is not provided the possibility of introducing the appeal in matters relating to legal conclusion of the agreement. In this way, the agreement cannot be invalidated for harming the consent.

Also through the provisions of the implementation law, there have been developed disposures concerning the solutions delivered as a result of processing the appeal. 
Thus, the Court of appeal may decide one of the following:

a) rejects the appeal, maintaining the contested decision, whether the appeal is late or inadmissible or unfounded;

b) allowes the appeal, dissolving sentence whereby the agreement has been upheld only with respect to the manner and amount of punishment or form of its execution and pronounces a further judgement, acting under art. 485 (1) letter a), which shall apply accordingly;

c) allowes the appeal, dissolves sentence, whereby the agreement was rejected, allowes the plea bargaining, art. 485 (1)letter a) and art. 486 applying properly.

\section{Conclusions}

The study analyzed the institution of plea bargaining agreement, both from the perspective of the new Romanian Code of Criminal Procedure, as well as of the amendments brought by the implementation law.

Without issuing the claim that through our approach the vast theme has been fully addressed, we believe that through advanced theoretical considerations we have managed to bring into focus the main issues which will arise from the institution and to identify possible preferable legislative solutions.

Whereas at the time of entry into force of the new Romanian Code of Criminal Procedure, the criminal trial will suffer a radical transformation, and fundamental safeguards such as the presumption of innocence, the right to silence and to self disincrimination, the right to propose the witnesses and to hear prosecution witnesses, and, generally, the right to a fair trial will be redrawn, to an extent not neglected, as the imperatives of inquisitorial justice will mitigate substantially, the subject of current interest both for theoreticians, especially for law practitioners, considering the multitude of problems that will arise in this metter, in jurisprudence of the Courts.

\section{Bibliography}

R. Motica, coord., Noile Coduri ale României, „Universul Juridic” Publishing House, Bucharest, 2011.

Gr. Theodoru, Tratat de drept procesual penal, „Hamangiu” Publishing House, Bucharest, 2007.

V. Rotaru, Acordul de recunoaştere a vinovăției ca formă specială a răspunderii penale, ,CEO USM” Publishing House, Chişinău, 2004.

S. Siserman., Considerații privind acordul de recunoaştere a vinovăției, available online at http://www.juridice.ro/163263/consideratii-privind-acordul-de-recunoastere-avinovatiei.html 